\title{
PEMIDANAAN TERHADAP PECANDU NARKOTIKA DI INDONESIA DITINJAU DARI ASPEK TUJUAN PENEGAKAN HUKUM
}

\author{
Akwila Arif Athallah, Kayus Kayowuan Lewoleba \\ Fakultas Hukum Universitas Pembangunan Nasional Veteran Jakarta \\ akwilaarif69@gmail.com,agnespulo@gmail.com
}

\begin{abstract}
Abstrak
Pemidanaan terhadap pecandu narkotika terdapat dua sisi pandangan dalam aspek penegakan hukumnya. Pecandu narkotika dipandang sebagai korban berdasarkan sudut pandang ilmu kesahatan serta dari aspek hukum karena di dalam UU Narkotika pencandu narkotika dianggap sebagai orang sakit yang perlu mendapatkan rehabilitasi, akan tetapi didalam kenyataannya seringkali pecandu narkotika diperlakukan sebagai penjahat dan dijatuhi hukuman berupa pidana penjara dalam proses penegakan hukum di Indonesia. Dalam penelitian ini, pemidanaan terhadap pecandu narkotika di Indonesiaakan ditinjau berdasarkan aspek tujuan penegakan hukum. Metode penelitian yang digunakan yuridis normatif dengan sumber data utama adalah studi kepustakaan. Pendekatan masalah yang digunakan adalah pendekatan teoritis dan analisa putusan. Hasil penelitian menunjukkan bahwa pemidanaan bagi pecandu narkotika di Indonesia tidak sesuai dengan tujuan dari penegakan hukum yaitu keadilan, kemanfaatan, dan kepastian hukum.Pemidanaan berupa pidana penjara terhadap pecandu narkotika di Indonesia juga dinilai tidak efektif, karena dinilai tidak mampu memperbaiki para pecandu narkotika maupun menimbulkan dampak positif bagi masyarakat dan negara.
\end{abstract}

\section{Kata kunci: Narkotika, Pecandu Narkotika, Tujuan Penegakan Hukum.}

\section{Abstract}

Penalties for narcotics addicts have two sides of view in the aspect of law enforcement. Narcotics addicts are seen as victims from a medical point of view as well as from the legal aspect because in the Narcotics Act narcotics addicts are considered as sick people who need to get rehabilitation, but in reality often narcotics addicts are treated as criminals and sentenced in the form of imprisonment in the enforcement process law in Indonesia. In this study, the punishment of narcotics addicts in Indonesia will be reviewed based on the aspects of law enforcement objectives. The research method used by normative juridical with the main data source is literature study. The problem approach used is the theoretical approach and decision analysis. The results of the research show that criminal punishment for narcotics addicts in Indonesia is not in accordance with the objectives of law enforcement, namely justice, expediency, and legal certainty. The conviction in the form of imprisonment of narcotics addicts in Indonesia is considered ineffective, because it is considered unable to improve narcotics addicts or to have a positive impact on society and the country.

\section{Keywords: Narcotics, Narcotics Addicts, Law Enforcement Objectives.}

\section{A. Pendahuluan}

Penyalahgunaan narkotika dalam beberapa tahun terakhirmasih menjadi persoalan bagi bangsa Indonesia. Jumlah kasus maupun korban penyalahgunaan narkotika selalu bertambah dari tahun ke tahun, selain itu korban penyalahgunaan narkotika di Indonesia kini telah melampaui batasan umur, strata sosial, dan jenis kelamin. Siapapun orangnya pada masa kini dapat menjadi korban dari penyalahgunaan narkotika. Tidak hanya merambah di wilayah per- 
kotaan saja, akan tetapi penyalahgunaan narkotika telah menembus wilayah pedesaan serta telah melampaui batas negara yang tentunya hal ini dapat berpotensi merugikan peradaban suatu negara serta generasi muda sebagai generasi penerus bangsa. Dengan semakin menyebarnya peredaran narkotika yang menyasar generasi muda, maka hal ini dapat menjadi suatu persoalan besar bagi bangsa ini di masa yang akan mendatang. ${ }^{1}$

Merujuk pada data Badan Narkotika Nasional (BNN), prevalensi jumlah penyalahgunaan narkotika di kalangan pelajar pada 13 ibu kota provinsi di Indonesiatahun 2018 menyentuh presentase sebesar 3,2 persen, yang artinya setara 2,29 juta orang. Sedangkan di tahunsebelumnya, jumlah prevalensi penyalahgunaan narkotikapada rentang usia 10-59 tahuntercatat sebanyak 1,77 persen yang artinya setara 3.376.115 orang. ${ }^{2}$ Data tersebut juga diperkuat oleh pernyataan dari Kepala Badan Narkotika Nasional (BNN) Komisiaris Jenderal Polisi Heru Winarko yang menyebut, 'penyalahgunaan narkotika di kalangan remaja makin meningkat. Di mana ada peningkatan sebesar 24 hingga 28 persen remaja yang menggunakan narkotika'. ${ }^{3}$ Secara keseluruhan, menurut data yang dikeluarkan oleh BNN angka penyalahgunaan narkotika di Indonesia pada tahun 2017 mencapai 3,5 juta jiwa. ${ }^{4}$ Sedangkan di tahun 2019 angka pe-

\footnotetext{
${ }^{1}$ A. Kadarmanta, Narkoba Pembunuh Karakter Bangsa, Depok, PT. Forum Media Utama, 2010, h. 128.

2 ،'Penggunaan Narkotika di Kalangan Remaja Meningkat',

$<$ https://nasional.kompas.com/read/2019/06/26/1142 1691/bnn-sebut-penyalahgunaan-dan-peredarannarkotika-semakin-meningkat>. Diakses tanggal 2 Oktober 2019, Pukul 01.30 WIB.

3 "' Penggunaan Narkotika di Kalangan Remaja

Meningkat'" $<$ https://bnn.go.id/penggunaannarkotika-kalangan-remaja-meningkat/>. Diakses tanggal 2 Oktober 2019, Pukul 01.40 WIB.

${ }^{4}$ BNN: Pemakai Narkoba di Indonesia Capai 3,5 Juta Orang pada 2017

$<$ https://www.liputan6.com/news/read/3570000/bnnpemakai-narkoba-di-indonesia-capai-35-juta-orang-
}

nyalahgunaan narkotika diIndonesia mencapai 3,6 juta jiwa. ${ }^{5}$ Ini artinya telah terjadi peningkatan sebesar kurang lebih sebesar seratus ribu pengguna narkotika selama tiga tahun ini.

Hal inilah yang menjadi bukti bahwa permasalahan penyalahgunaan narkotika di Indonesia kini sangat perlu mendapatkan penanganan serius dari negara. Hal ini perlu dilakukan untuk menekan angka penyalahgunaan narkotika yang semakin bertambah dari waktu ke waktu, serta tidak lain bertujuan untuk menyelamatkan masa depan bangsa Indonesia. Selain itu, negara juga berkewajiban untuk membina masyarakat terdampak peredaran gelap narkotika, termasuk pecandu narkotika. Selain dari kewajiban untuk melindungi hak-hak dari warga negaranya, hal ini juga disebabkan karena negara melalui pemerintah memiliki fasilitas, aparat, ataupundana yang cukup apabila dibandingkan dengan pihak swasta, maka sudah seharusnya negara sanggup untuk mengadakan pembinaan bagi warga negaranya yang sudah terlanjur terpapar narkotika. ${ }^{6}$ Kewajiban untuk memberi perawatan serta membina pecandu narkotika ini juga telah tercantum di dalam Pasal 54 UndangUndang Nomor 35 Tahun 2009 Tentang Narkotika yang berbunyi "Pecandu Narkotika dan korban penyalahgunaan Narkotika wajib menjalani rehabilitasi medis dan rehabilitasi sosial".

Akan tetapi permasalahan kemudian timbul akibat padaundang-undang tersebut tercantum pula pasal-pasal yang memungkinkan pemidanaan berupa hukuman penjarabagi seorang penyalah guna narkotika. Salah satunya adalah Pasal 127 Ayat (1) Undang-Undang Nomor 35 Tahun 2009

pada-2017>. Diakses tanggal 8 April 2020, Pukul $22.41 \mathrm{WIB}$

5 Kepala BNN: Pengguna Narkoba pada 2019

Tembus 3,6 Juta Orang

$<$ https://www.liputan6.com/news/read/4127338/kep ala-bnn-pengguna-narkoba-pada-2019-tembus-36juta-orang $>$. Diakses tanggal 8 April 2020, Pukul 22.45 WIB

${ }^{6}$ Gatot Supramono, Hukum Narkoba

Indonesia, Jakarta, Djambatan, 2009, h. 193. 
Tentang Narkotika. Hal ini tentu menimbulkan suatu kerancuan, karena secara logika seorang pecandu narkotika tentu juga merupakan seorang penyalah guna narkotika serta di lain sisi dapat pula dipandang selaku seorang korban dari penyalahgunaan narkotika atau kejahatan yang dilakukan oleh dirinya sendiri. ${ }^{7}$ Begitupun dengan pasal-pasal lainnya seperti pada Pasal 111 hingga Pasal 115undang-undang tersebut, yang mana pada pasal-pasal tersebut terkandung beberapa unsur yang dapat menjerat pecandu narkotika untuk dijatuhi hukuman berupa pidana penjara.Hal ini tentu menjadi problematika tersendiri terhadap penegakan hukum bagi seorang pecandu narkotika, karena di satu sisi seorang pecandu narkotika dipandang sebagai korban dan apabila mengacu pada Undang-Undang Nomor 35 Tahun 2009 Tentang Narkotika, maka seorang pecandu narkotika wajib untuk di rehabilitasi, baik rehabilitasi medis maupun rehabilitasi sosial. Akan tetapi dikarenakan adanya pasal-pasal tersebut,seorang pecandu narkotika terancam kehilangan haknya untuk mendapatkan penyembuhan, bahkan seorang pecandu narkotika terancam dijatuhi hukuman berupa pidana penjara.

Sebenarnya hal ini telah coba diantisipasi melalui Surat Edaran Mahkamah Agung No 4 Tahun 2010 tentang Penempatan Penyalahgunaan, Korban Penyalahgunaan dan Pecandu Narkotika ke Dalam Lembaga Rehabilitasi. Pada intinya peraturan ini mencoba memberikan penguatan atas upaya penjatuhanrehabilitasi bagi pecandu narkotika. Namun pada kenyataannya, masih saja banyak para pecandu narkotika yang dikenakan pidana penjara dengan alasan karena terbukti memenuhi unsur-unsur pada pasalpasal yang mengatur pemidanaan bagi penyalahgunaan narkotika.Yang mana sebenarnya apabila ditinjau lebih jauh, tidak seharusnya seorang pecandu narkotika dija-

\footnotetext{
${ }^{7}$ A.A. Istri. "Perlindungan Hukum Terhadap Korban Penyalahguna Narkotika Dengan Berlakunya Undang-Undang Nomor 35 Tahun 2009 Tentang Narkotika”, Jurnal Fakultas Hukum Universitas Udayana, Denpasar, 2012, h.3.
}

tuhi pidana berupa penjara, hal ini disebabkan pemidanaan itu sendiri yang berwujud suatu nestapa yang dengan sengaja ditimpakan negara pada pembuat delik ${ }^{8}$ serta lebih menitikberatkan pada suatu penjatuhan derita. ${ }^{9}$ Pemidanaan identik digambarkan sebagai suatu pemberian derita dan penderitaan tersebut mutlak harus dirasakan oleh pelaku tindak pidana tersebut. ${ }^{10}$

Dengan mempertimbangkan kondisi ketergantungan yang dialami seorang pecandu narkotika, tidak salah apabila mereka kerap kali disebut sebagai pesakitan atau orang sakit yang seharusnya diberikan perawatan berupa rehabilitasi guna lepas dari dampak-dampak buruk akibat penyalahgunaan narkotika. Selain itu kedudukan pecandu narkotika memang dapat dipandang sebagai seorang korban dari peredaran gelap narkotika yang terjadi. Sehingga sudah seharusnya penegakan hukum yang diberlakukan bagi para pecandu narkotika bersifat rehabilitatif serta lebih menitikberatkan pada pemberian hukuman yang dapat dijadikan sarana perbaikan atau pendidikan bagi pecandu narkotika. ${ }^{11}$ Karena pada dasarnya hukum ada untuk memenuhi beberapa tujuan, yang mana tujuan-tujuan tersebut pada intinya berfungsi untuk mengatur ketentraman, kenyamanan, serta mengatur pergaulan hidup secara damai dalam kehidupan bermasyarakat. $^{12}$ Adapun tujuan dari ditegakkannya hukum terbagi menjadi 3 garis besar, yaitu untuk keadilan, kemanfaatan, serta kepastian hukum. Sehingga Berdasarkan uraian latar belakang permasalahan tersebut, maka yang menjadi rumusan masalah

\footnotetext{
${ }^{8}$ Eva Achjani Zulfa dan Indriyanto Seno Adji, Pergeseran Paradigma Pemidanaan,Bandung, CV Lubuk Agung, 2011, h. 10.

9 Eddy O.S. Hiariej, Prinsip-Prinsip Hukum Pidana, Yogyakarta, Cahaya Atma Pustaka, 2016, h. 452.

${ }^{10}$ Eva Achjani Zulfa dan Indriyanto Seno Adji, Op.Cit., h. 51.

${ }^{11}$ E.Y. Kanter dan S.R. Sianturi, Asas-Asas Hukum Pidana Di Indonesia dan Penerapannya, Jakarta, Storia Grafika, 2002, h. 70.

${ }^{12}$ L.J. van Apeldoorn, Pengantar Ilmu Hukum, Jakarta, PT Pradnya Paramita, 2013, h. 11.
} 
di dalam penelitian ini adalah bagaimana pemidanaan terhadap seorang pecandu narkotika di Indonesia jika ditinjau dari aspek tujuan penegakan hukum dan bagaimana dampak yang ditimbulkan dari pemidanaan yang dijatuhkan terhadap seorang pecandu narkotika.Selain itu di dalam penelitian ini penulis juga akanmenganalisis putusan pengadilan terkait dengan pemidanaan terhadap pecandu narkotika, yaitu Putusan Pengadilan Negeri Jakarta Selatan Nomor 848/Pid.Sus/2018/PN JKT.SEL.

\section{B. Metode Penelitian}

Metode dari penelitian ini adalah yuridis normatif, yang mengutamakan pada penggunaan data sekunder dalam pelaksanaan penelitiannya. Penelitian ini menggunakan pendekatan teoritisdan analisa putusan mengenai pemidanaan terhadap pecandu narkotika sebagai pendekatan permasalahannya, yang kemudian menggunakan aspek tujuan penegakan hukum sebagai tinjauannya, yang tetap mengacu pada hukum positif di Indonesia.Adapun sumber data penelitian ini berupa sumber data sekunder, yang terdiri dari sumber bahan hukum primair yaitu terdiri dari peraturan perundangundangan serta putusan pengadilan. Di dalam penelitian ini penulis akan berfokus pada Undang-Undang Nomor 35 Tahun 2009 tentang Narkotika, yang mana menjadi peraturan hukum yang utama bagi tindak pidana narkotika di Indonesia. Selain itu, penulis juga akan menggunakan peraturan-peraturan terkait dengan tindak pidana narkotika. Adapun sumber bahan hukum sekunder yang penulis gunakan terdiri atas jurnal hukum, buku teks, yurisprudensi, pendapat para pakarterkait pemidanaan, tindak pidana narkotika, maupun ilmu hukum secara umum.Serta sumber bahan hukum tersier yang terdiri atas bahan hukum yang bersumber pada kamus hukum serta ensiklopedia terkait pemidanaan, tindak pidana narkotika maupun ilmu hukum secara umum.

Teknik analisis data yang digunakan adalah Deskriptif Analisis. Penulis akan berfokus pada permasalahan pemidanaan bagi pecandu narkotika serta tinjauannya terhadap aspek tujuan penegakan hukum. Setelah permasalahan dijelaskan atau digambarkan secara rinci dan sistematis, penulis juga akan membuat analisis terhadap pemecahan dari permasalahan tersebut, yang tentu saja semua hal tersebut penulis dapatkan dari sumber bahan hukum yang ada.

\section{PEMBAHASAN \\ 1. Analisis PutusanNomor 848/Pid.Sus/- 2018/PN JKT.SEL}

Bahwa pada kasus dari putusan ini diketahui terpidana didakwakan dengan $\mathrm{Pa}$ sal 112 ayat (1) Undang-Undang Republik Indonesia Nomor 35 Tahun 2009 Tentang Narkotika subsidair Pasal 127 ayat (1) Undang-Undang Nomor 35 Tahun 2009 Tentang Narkotika. Terpidana dinilai sudah memenuhi beberapa unsur dari pasal-pasal tersebut yakni "tanpa hak atau melawan hukum memiliki, menyimpan, menguasai, atau menyediakan narkotika jenis shabu" yang diatur di dalam Pasal 112 ayat (1) serta "penyalahgunaan narkotika Golongan I bagi diri sendiri" yang diatur pada Pasal 127 ayat (1). Pada akhirnya berdasarkan putusan hakim yang memutus perkara tersebut, terpidana dihukum denganpidana penjara selama 4 tahun serta dikenakan denda Rp.800.000.000,- (delapan ratus juta rupiah), sesuai dakwaan primair yang dijatuhkan terhadapnya.

Kasus tersebut hanya satu dari sekian banyak kasus serupa yang berujung pada pemidanaan bagi pecandu narkotika. Yang menjadi perhatian penulis dari putusan di atas adalah tidak adanya putusan berupa penjatuhan sanksi tindakan berupa rehabilitasi yang mana hal ini menurut penulis sangat penting bagi terpidana itu sendiri. Berdasarkan fakta yang tertulis pada surat dakwaan dari putusan tersebut, menurut pengakuan terpidana dirinya telah mengonsumsi atau menggunakan narkotika jenis shabu selama satu tahun. Yang mana waktu tersebut bukanlah waktu yang singkat dan berpotensi sangat membahayakan bagi tubuh terpidana baik secara fisik maupun psikis. Meskipun menurut hasil asesmen terpidana 
termasuk dalam pengguna yang bersifat situasional yaitu yang tidak mengalami kecanduan secara akut, akan tetapi dalam jangka waktu satu tahun penggunaan narkotika jenis shabu pasti telah memiliki dampak bagi terpidana tersebut.

Karena hal tersebutlah seharusnya terpidana mendapatkan pengobatan baik berupa detoksifikasi yaitu tahapan yang ditujukan guna menetralisir racun akibat narkoba, rehabilitasi yang ditujukan agar seorang pemakai dapat kembali hidup secara normal dan tahap tindak lanjut lainnya. ${ }^{13}$ Selain itu yang penulis ingin soroti dari putusan tersebut adalah bagaimana para aparatur penegak hukum di Indonesia khususnya penuntut umum lebih sering menggunakan pasal-pasal yang berbau kriminalisasi terhadap para pecandu narkotika. Hal ini terbukti bahwa dalam surat dakwaan pada putusan ini, Jaksa Penuntut Umum menggunakan Pasal 112 yang mana pada putusan akhirnya hakim turut memutus perkara tersebut dengan berpedoman pada pasal tersebut. Begitu pula dengan hakim, menurut pandangan penulis seharusnya hakim lebih memperhatikan ketentuan yang tertulis di dalam Surat Edaran Mahkamah Agung Nomor 4 Tahun 2010 Tentang Penempatan Penyalahgunaan, Korban Penyalahgunaan dan Pecandu Narkotika ke Dalam Lembaga Rehabilitasi Medis dan Rehabilitasi Sosial. Di dalam aturan tersebut hakim sebenarnya sangat dimungkinkan untuk menjatuhkan rehabilitasi bagi terdakwa kasus penyalahgunaan narkotika, meskipun dapat dijatuhkannya ketentuan tersebut harus memenuhi beberapa persyaratan atau klasifikasi, adapun persyaratan-persyaratan yang terkandung pada SEMA Nomor 4 Tahun 2010 tersebut apabila dicocokan dengan kasus pada putusan tersebut adalah sebagai berikut:

\footnotetext{
${ }^{13}$ Hari Sasangka, Narkotika dan Psikotropika Dalam Hukum Pidana Untuk Mahasiswa dan Praktisi serta Penyuluh Masalah Narkoba, Bandung, Mandar Maju, 2003, h. 27.
}

1. "Terdakwa pada saat ditangkap oleh penyidik Polri dan penyidik BNN dalam kondisi tertangkap tangan"

Terdapat empat kemungkinan diketahui terjadinya delik yaitu kedapatan tertangkap tangan, karena laporan, karena pengaduan, atau diketahui sendiri atau pemberitahuan atau dengan cara lainnya sehingga penyidik dapat mengetahui terjadinya suatu delik seperti mendengar dari radio, membacanya di surat kabar, atau mendengar dari orang bercerita, dan cara lainnya. ${ }^{14}$ Adapun kondisi terpidana saat tertangkap adalah dengan kondisi tertangkap tangan di rumah kontrakannya. Sehingga apabila ditinjau dari persyaratan ini maka kasus dalam putusan ini telah memenuhinya.

2. "Pada saat tertangkap tangan ditemukan barang bukti pemakaian 1 (satu) hari dengan narkotika jenis shabu maksimal sebanyak 1 gram"

Pada kasus diputusan tersebut barang bukti yang diamankan dari terpidanaadalah berupanarkotika jenis shabu seberat 0,1162 Gram. Sehingga apabila mengacu pada prasyarat ini, barang bukti yang di temukan pada terpidana pada saat tertangkap tangan berada di bawah batas maksimal jumlah berat yang ditentukan pada persyaratan ini. Sehingga kasus pada putusan tersebut telah memenuhi prasyarat dari klasifikasi ini.

3."Surat uji Laboratorium positif menggunakan Narkotika berdasarkan menggunakan Narkotika berdasarkan permintaan penyidik"

Bahwa berdasarkan surat dari Badan Narkotika Nasional Republik Indonesia Kota Jakarta Selatan Nomor R/197/V/Ka/rh.00.04/2018/BNNK-JAKSEL bahwa benar terpidana terbukti merupakan pengguna narkotika jenis shabu. Sehingga persyaratan dari klasifikasi ini penulis nilai telah terpenuhi.

4. "Perlu surat keterangan dari dokter jiwa/psikiater pemerintah yang ditunjuk oleh hakim"

\footnotetext{
${ }^{14}$ Andi Hamzah, Hukum Acara Pidana Indonesia, Jakarta, Sinar Grafika, 2017, h. 121.
} 
Bahwa pada putusan kasus ini tidak tercantum surat keterangan dari dokter jiwa/psikiater pemerintah yang ditunjuk oleh hakim. Akan tetapi, pada kasus ini terpidana telah diperiksa Tim Asesmen Terpadu yang mana pada pemeriksaan ini meliputi dua proses asesmen yaitu asesmen yang diperiksa oleh Tim Hukum serta Tim Dokter, yang mana Tim Dokter ini memilikikewajiban untuk melakukan asesmen serta menganalisa secara medis, psikososial dan merekomendasikan rencana terapi serta rehabilitasi bagi penyalaguna narkotika. ${ }^{15}$ Dan berdasarkan surat dari Badan Narkotika Nasional Republik Indonesia Kota Jakarta Selatan Nomor R/197/V/Ka/rh.00.04/2018/BNNK-JAKSEL tanggal 28 Mei 2018 tentang rekomendasi rehabilitasi atas nama terdakwa yang kesimpulannya Tim Asesmen Terpadu menemukan fakta bahwa terdakwa merupakan penyalahguna shabu dengan pola penggunaan situasional, dan direkomendasikan untuk menjalani rehabilitasi. Sehingga penulis menilai prasyarat ini telah pada kasus pada putusan tersebut.

5. "Tidak terdapat bukti bahwa yang bersangkutan terlibat dalam peredaran gelap Narkotika"

Hampir sama seperti halnya pada persyaratan klasifikasi sebelumnya, pada persyaratan ini diperlukan adanya suatu asesmen yang mana hal ini ditujukan untuk membuktikan bahwa terdakwa tidak memiliki keterlibatan dalamsuatu peredaran gelap narkotika. Di dalam persyaratan ini yang di perlukan adalah hasil asesmen yang dari Tim Hukum. Tim Hukum bertugas untuk menganalisa apakah terdakwa terlibat atau tidak dalam peredaran gelap narkotika dan prekursor narkotik, dalam menjalankan tugasnya Tim Hukum juga turut berkoordinasi bersama penyelidik yang menangani perkara. ${ }^{16}$ Bahwa berdasarkan surat dari Badan Narkotika Nasional Republik Indo-

\footnotetext{
${ }^{15}$ Ratna WP, Aspek Pidana: Penyalahgunaan Narkotika Rehabilitasi Versus Penjara (Menyoroti Pasal 127 UU No. 35 Tahun 2009), Yogyakarta, LEGALITY, 2017, h. 30.

${ }^{16}$ Ibid. h. 29.
}

nesia Kota Jakarta Selatan Nomor R/197/$\mathrm{V} / \mathrm{Ka} / \mathrm{rh} .00 .04 / 2018 / \mathrm{BNNK}-J A K S E L$ setelah dilakukan asesmen hukum yang dilakukan terhadap terpidana menghasilkan kesimpulan bahwa terpidana tidak terindikasi terlibat dalam jaringan peredaran gelap narkotika. Sehingga prasyarat dari klasifikasi ini penulis nilai telah terpenuhi.

Berdasarkan tinjauan-tinjauan tersebut dapat ditarik kesimpulan bahwa kasus di dalamputusan ini telah memenuhi kelima persyaratan yang diklasifikasikan pada Surat Edaran Mahkamah Agung Nomor 4 Tahun 2010 tersebut. Artinya hakim yang memutus perkara ini sebenarnya sangat memungkinkan untuk menjatuhkan putusan rehabilitasi kepada terpidana. Akan tetapi pada akhirnya hakim lebih memilih menjatuhkan pidana penjara dibandingkan putusan rehabilitasi yang sebenarnya akan lebih bermanfaat untuk terpidana. Hal ini sangat disayangkan, karena menurut penulis penjatuhan putusan yang ditujukan untuk perbaikan pada diri terpidana seharusnya lebih diutamakan dibandingkan dengan penjatuhan derita semata.

\section{Pemidanaan Terhadap Pecandu Nar- kotika Ditinjau Dari Aspek Keadilan Se- bagai Tujuan Penegakan Hukum}

Keadilan seringkali diartikan sebagai perlakuan atau pemberian yang sama rata, akan tetapi pada faktanya keadilan tidak dapat diartikan sebagai persamaan perlakuan semata. Terkadang keadilan juga diberikan dengan memerhatikan beberapa faktor seperti kebutuhan khusus pada diri seseorang, suatu perbedaan keadaan, maupun faktorfaktor lainnya. Pada dasarnya keadilan dapat dimaknai secara beragam, sehingga seringkali menimbulkan perbedaan dan pertentangan pendapat di dalam penafsirannya. Seorang filsuf asal Yunani, Plato berpendapat bahwa makna sebenarnya dari keadilan adalah kemampuan memperlakukan setiap orang berdasarkan haknya masingmasing. Pemahaman atau pendapat Plato mengenai keadilan itu juga turut dipertahankan sepanjang sejarah kebudayaan Barat melalui Aristoteles, Cicero, Agustinus dan 
juga oleh sistem hukum Romawi yang masih punya pengaruh kuat hingga sekarang ini. ${ }^{17}$ Hingga pada akhirnya keadilan dianggap merupakan menjadi salah satu tujuan penting dari diciptakan dan ditegakannya hukum di tengah masyarakat.

Keadilan dimata hukum telah diadopsi melalui asas persamaan di depan hukum (equality before law) sebagai salah satu ciri dari hukum yang berlaku pada negara hu$\mathrm{kum}^{18}$, termasuk negara Indonesia. Hal ini turut pula diatur di dalam Pasal $28 \mathrm{D}$ ayat (1) Undang-Undang Dasar Negara Republik Indonesia Tahun 1945 yang berbunyi: "Setiap orang berhak atas pengakuan, jaminan, perlindungan, dan kepastian hukum yang adil, serta perlakuan yang sama di hadapan hukum." Kesamaan perlakuan di hadapan hukum merupakan suatu tonggak penting dalam terwujudnya keadilan sebagai tujuan penegakan hukum. Dengan adanya persamaan perlakuan dalam suatu penyelesaian perkara pidana khususnya pada kasus yang serupa dengan kasus yang lainnya diharapkan dapat memenuhi rasa keadilan kepada para pihak.Akan tetapi faktanya pada penyelesaian perkara yang melibatkan pecandu narkotika di Indonesia masih seringkali terdapat perbedaan dalam penyelesaiannya.

Hal ini terutama terjadi pada tahap putusan yang diberikan hakim terhadap perkara yang melibatkan pecandu narkotika. Putusan hakim yang kerap berbeda-beda pada kasus serupa ini disebut sebagai disparitas putusan. Terhadap beberapa perkara pidana yang melibatkan pecandu narkotika, beberapa hakim terkadang menjatuhkan putusan berupa hukuman pidana penjara bagi pecandu narkotika. Akan tetapi dalam beberapa kasus, terdapat pula hakim yang menjatuhkan putusan berupa hukuman re-

\footnotetext{
${ }^{17}$ Arbijoto, Kebebasan Hakim Analisis Kritis Terhadap Peran Hakim Dalam Menjalankan Kekuasaan Kehakiman, Jakarta, Diadit Media, 2010, h. 55 .

${ }^{18}$ Bambang Waluyo, Penegakan Hukum Di Indonesia, Jakarta, Sinar Grafika, 2016 (selanjutnya disingkat Bambang Waluyo I), h. 20.
}

habilitasi. Yang turut menjadi perhatian pula, seringkali putusan penjatuhan hukuman rehabilitasi ini kerap dijatuhkan kepada tersangka publik figur atau pesohor ${ }^{19}$, sehingga hal ini kerap menjadi perhatian dari masyarakat yang mempertanyakan hukuman apa yang berlaku dan seharusnya dijatuhkan terhadap pecandu narkotika.

Sebut saja pada perkara penyalahgunaan narkotika yang melibatkan beberapa publik figure ternama seperti Ello yang berujung pada penjatuhan hukuman rehabilitasi selama sembilan bulan, perkara yang melibatkan Restu Sinaga yang berujung pada penjatuhan rehabilitasi selama enam bulan, dan kasus Ridho Rhoma yang berujung pada penjatuhan rehabilitasi selama enam bulan sepuluh hari berdasarkan Putusan Nomor 1104/Pid.Sus/2017/PN.Jkt.Brt yang kemudian dikuatkan dengan Putusan Nomor 309/PID.SUS/2017/PT.DKI. Perkaraperkara tersebut berkaitan dengan penyalahgunaan narkotika, akan tetapi berujung pada penjatuhan hukuman rehabilitasi oleh hakim. Bandingkan saja dengan Putusan Nomor 848/Pid.Sus/2018/PN JKT.SEL yang sebelumnya telah dianalisa, dimana terdakwa di dakwakan dengan pasal-pasal yang sangat memberatkan terdakwa yang berujung pada penjatuhan hukuman pidana penjara bagi terdakwa.

Disparitas putusan hakim ini sebenarnya sah-sah saja terjadi dalam suatu sistem peradilan pidana, hal ini mungkin saja terjadi dikarenakan terjadinya perbedaan sudut pandang dari para hakim itu sendiri, hal yang lumrah terjadi pada setiap manusia. Akan tetapi disparitas putusan terkait perkara yang melibatkan pecandu narkotika ini tentu saja memiliki dampak buruk, seperti tercederainya rasa keadilan para pihak atau pecandu narkotika yang dijatuhi pidana penjara, timbulnya kecumburuan sosial maupun kecurigaan pada masyarakat luas terkait pengaruh strata sosial dalam penjatu-

\footnotetext{
${ }^{19}$ Anang Iskandar, Penegakan Hukum Narkotika Rehabilitatif terhadap Penyalah Guna dan Pecandu Represif terhadap Pengedar, Jakarta, PT Elex Media Komputindo, 2019, h. 65.
} 
han hukuman. Selain itu pengadilan seharusnya dapat menjadi suatu proses akhir dari penyelesaian suatu perkara pada hakikatnya berguna untuk membantu para pencari keadilan dan memenuhi cita-cita dari adanya peradilan itu sendiri yaitu menghadirkan rasa keadilan dan kebenaran, serta kepastian hukum. ${ }^{20}$ Dengan adanya perbedaanperbedaan penyelesaian suatu kasus serupa ini menyebabkan aspek keadilan sebagai salah satu tujuan penegakan hukum di dalam penjatuhan pidana penjara bagi pecandu narkotika dinilai belum dapat terpenuhi.

\section{Pemidanaan Terhadap Pecandu Nar- kotika Ditinjau Dari Aspek Kepastian Hukum Sebagai Tujuan Penegakan Hu- kum}

Kepastian dari atau dalam hukum, adalah suatu kepastian yang dapat dicapai jika hukum sebanyak-banyaknya berbentuk undang-undang. Dengan ketentuan bahwa pada suatu undang-undang tidak memuat ketentuan yang saling berlawanan, undangundang itu dibuat berlandaskan keadaan hukum yang sebenarnya, serta pada undang-undang tidak terdapat peristilahan yang dapat diartikan berbeda satu dengan lainnya. Kepastian hukum juga mengandung arti bahwa suatu hukum harus pasti dan tidak mudah untuk berubah, sehingga setiap peristiwa dapat dengan mudah ditentukan merupakan suatu perbuatan yang dilarang hukum atau tidak. ${ }^{21}$ Sehingga pada akhirnya kepastian hukum berfungsi untuk memastikan bahwa hukum benar-benar dapat dijalankan dengan sebenar-benarnya dan ditaati oleh masyarakat. ${ }^{22}$

Di Indonesia tindak pidana narkotika termasuk ke dalam tindak pidana khusus, sehingga pengaturannya diatur tersendiri melalui undang-undang khusus diluar dari

\footnotetext{
${ }^{20}$ Bambang Waluyo I, Op.Cit., h. 23

${ }^{21}$ Edi Setiadi dan Kristian, Sistem Peradilan Pidana

Terpadu dan Sistem Penegakan Hukum di

Indonesia, Jakarta, Prenadamedia Group, 2017, h. 148.

${ }^{22}$ Ibid.
}

Kitab Undang-Undang Hukum Pidana. ${ }^{23}$ Pengaturannya telah diatur di dalam Undang-Undang Nomor 35 Tahun 2009 Tentang Narkotika. Undang-undang tersebut merupakan sumber hukum yang utamaserta menjadi dasar dari penegakan hukum terhadap tindak pidana narkotika, begitupun pengaturan yang mengatur mengenai pecandu narkotika. Meskipun seperti yang sudah diuraikansebelumnya, pengaturan mengenai pecandu narkotika di dalam undang-undang ini seolah terbagi ke dalam dua sisi sudut pandang yaitu dari sudut pandang ilmu kesehatan yang menekankan bahwa seorang pecandu narkotika adalah seorang pesakitan yang mana perlu dan wajib untuk di jatuhi tindakan rehabilitasi, dan dari sudut pandang hukum pidana yang mana memandang bahwa pecandu narkotika merupakan pelaku tindak pidana yang memungkinkan untuk dikenakan hukuman penjara.

Kedua sudut pandang tersebut turut didukung oleh beberapa pasal yang terkandung pada Undang-Undang Nomor 35 Tahun 2009 Tentang Narkotika, yang mengakibatkanapabila ditafsirkan sekilas maka akan menimbulkan anggapan bahwa ketentuan-ketentuan mengenai pecandu narkotika pada undang-undang ini saling bertentangan sehingga menimbulkan suatu ketidakpastian hukum terkait pengaturan mengenai pecandu narkotika. Akan tetapi, untuk menafsirkan lebih dalam apa maksud yang ingin dituju oleh undang-undang ini terkait kebijakan negara terhadap para pecandu narkotika, maka perlu dilihat lebih dalam apa-apa saja yang sebenarnya menjadi tujuan diterbitkannya undang-undang ini. Adapun tujuan dari diterbitkannya undang-undang tersebut tercantum pada Pasal 4 UndangUndang Nomor 35 Tahun 2009, yang berbunyi: "Undang-Undang tentang Narkotika bertujuan: a. menjamin ketersediaan Narkotika untuk kepentingan pelayanan kesehatan dan/atau pengembangan ilmu pengetahuan dan teknologi; b. mencegah, melindungi,

\footnotetext{
${ }^{23}$ Ruslan Renggong, Hukum Pidana Khusus Memahami Delik-delik di Luar KUHP, Jakarta, Kencana, 2017, h. 28.
} 
dan menyelamatkan bangsa Indonesia dari penyalahgunaan Narkotika; c. memberantas peredaran gelap Narkotika dan Prekursor Narkotika; dan d. menjamin pengaturan upaya rehabilitasi medis dan sosial bagi Penyalah Guna dan pecandu Narkotika." Terkait pecandu narkotika dapat dilihat bahwa salah satu tujuan penting dari diterbitkannya undang-undang tersebut yaitu untuk memastikan serta menjamin pengaturan mengenai rehabilitasi yang diperuntukkan untuk penyalah guna dan pecandu narkotika.

Artinya, undang-undang ini mengamanatkan rehabilitasi sebagai suatu tindakan yang difokuskan dan ditujukan untuk diberikan bagi para pecandu narkotika. Tujuan ini juga menjadi dasar dari penjatuhan rehabilitasi yang diwajibkan untuk pencandu narkotika yang kemudian tertuang pada Pasal 54 undang-undang ini. Perlu digaris bawahi bahwa pada pasal tersebut terdapat frasa kata "wajib" yang berarti mewajibkan pecandu narkotika untuk menjalani rehabilitasi. ${ }^{24}$ Selain pada Pasal 54, untuk mewujudkan tujuan tersebut maka Undang-Undang Nomor 35 Tahun 2009 Tentang Narkotika juga menganut sistem peradilan rehabilitasi di samping sistem peradilan pidana, dimana pada sistem peradilan rehabilitasi memberikan alternatif pengganti hukuman penjara menjadi berupa penjatuhan hukuman rehabilitasi. ${ }^{25}$ Hal ini tercantum pada Pasal 103 ayat (2) Undang-Undang Nomor 35 Tahun 2009 yang berbunyi: "Masa menjalani pengobatan dan/atau perawatan bagi Pecandu Narkotika sebagaimana dimaksud pada ayat (1) huruf a diperhitungkan sebagai masa menjalani hukuman." Yang mana hal tersebut kemudian menyebabkan undang-undang ini disebut menganut ide Double Track System Pemidanaan, yang mana untuk pengedar mengikuti Track peradilan pidana, sedangkan penyalah guna,

\footnotetext{
${ }^{24}$ AR. Sujono dan Bony Daniel, Komentar Dan Pembahasan Undang-Undang Nomor 35 Tahun 2009 Tentang Narkotika, Jakarta, Sinar Grafika, 2013, h. 126.

${ }^{25}$ Anang Iskandar, Op.Cit.,h. 31.
}

pecandu narkotika, serta korban penyalahguna narkotika mengikuti Track peradilan rehabilitasi. ${ }^{26} \mathrm{Hal}$ ini pada intinya memiliki tujuan untuk tetap memberikan efek jera serta melakukan fungsi pencegahan, oleh karena itulah rehabilitasi dan pidana penjara diatur secara bersamaan. ${ }^{27}$

Beralih dari ketentuan undang-undang, pada kenyataannya dalam proses penegakan hukum terhadap pecandu narkotika masih saja sering terjadi perbedaan pemahaman di antara aparat penegak hukum di Indonesia, sehingga terjadi pula perbedaan penanganan dalam setiap kasusnya. Fakta yang penulis temukan dari beberapa kasus yang melibatkan pecandu narkotika, Jaksa Penuntut Umum seringkali mendakwakan serta menuntut para pecandu narkotika ini dengan pasal-pasal yang sebenarnya ditujukan untuk pengedar narkotika, seperti Pasal 111 hingga Pasal 115 Undang-Undang Nomor 35 Tahun 2009 Tentang Narkotika. Yang mana pada pasal-pasal ituterkandung beberapa unsur yang hampir pasti dilakukan oleh pecandu narkotika, seperti unsur "membeli", "menyimpan" ataupun "menguasai" narkotika.Dengan terpenuhinya unsurunsur tersebut, pecandu narkotika lantas dianggap begitu saja telah melakukan tindak pidana serta menjadi pelaku dari tindak pidana. Hal ini berlanjut hingga pada tahap penjatuhan hukuman oleh hakim di dalam pengadilan, sehingga pada akhirnya pecandu narkotika yang memang terbukti memenuhi unsur-unsur yang diatur pada pasalpasal tersebut dijatuhkan hukuman berupa pidana penjara. Hal ini tentu sangat disayangkan karena seharusnya pasal-pasal tersebut diperuntukkan untuk para pengedar narkotika, bukan pecandu narkotika. Yang mana hal ini sebenarnya tidak sejalan dengan tujuan yang terkandung serta diamanatkan Undang-Undang Nomor 35 Tahun 2009 Tentang Narkotika yang justru meng

\footnotetext{
${ }^{26}$ Ibid. h. 32.

${ }^{27}$ Syaiful Bakhri, Tindak Pidana Narkotika dan Psikotropika Suatu Pendekatan Melalui Kebijakan Hukum Pidana, Jakarta, Gramata Publishing, 2012, h. 258.
} 
amanatkan penjatuhan rehabilitasi bagi para pecandu narkotika, sesuai dengan apa yang telah tertera pada tujuan dibuatnya undangundang tersebut.

Perbedaan pemahaman diantara para aparat penegak hukum tersebut akhirnya menimbulkan suatu ketidakpastian terkait penegakan hukum yang dikenakan terhadap pecandu narkotika. Salah satu tujuan penting diterbitkannya Undang-Undang Nomor 35 Tahun 2009 Tentang Narkotika menggantikan Undang-Undang Nomor 22 Tahun 1997 tentang Narkotika adalah terkait timbulnya kesadaran mengenai penjatuhan hukuman berupa rehabilitasi bagi para pecandu narkotika jauh lebih bermanfaat disbandingkan penjatuhan hukuman pidana penjara, namun hal tersebutnampaknya masih belum disadari betul oleh semua aparat penegak hukum di Indonesia. Bahkan setelah dikeluarkannya beberapa peraturan di luar peraturan perundang-undangan yang pada intinya mengutamakan penjatuhan rehabilitasi bagi pecandu narkotika, penulis menilai masih belum mampu menimbulkan kesepahaman di antara para aparat penegak hukum di Indonesia terkait penjatuhan hukuman bagi pecandu narkotika.

Perbedaan pemahaman tersebut kemudian berujung pada perbedaan penanganan dan penyelesaian dalam setiap kasus yang melibatkan pecandu narkotika, yang pada intinya terbagi menjadi dua garis besar yaitu penjatuhan pidana penjara dan penjatuhan hukuman berupa rehabilitasi bagi pecandu narkotika. Telah terdapat banyak contoh kasus yang melibatkan pecandu narkotika, dimana kasus-kasus tersebut serupa namun dengan penyelesaian yang berbeda. Hal ini, khususnya dalam pemidanaan bagi pecandu narkotika pada akhirnya menimbulkan suatu ketidakpastian hukum di tengah masyarakat. Ketidakpastian ini timbul akibat tidak sejalannya apa yang sebenarnya diatur di dalam peraturan perundang-undangan beserta peraturan-peraturan diluar undang-undang mengenai pecandu narkotika dengan kenyataan penegakan hukum bagi pecandu narkotika yang dilaku- kan oleh aparat penegak hukum sejauh ini. Sehingga penulis menilai bahwa pemidanaan yang dijatuhkan terhadap pecandu narkotika di Indonesia sekarang ini tidak dapat memenuhi aspek kepastian hukum sebagai tujuan dari penegakan hukum.

\section{Pemidanaan Terhadap Pecandu Nar- kotika Ditinjau Dari Aspek Kemanfaat- an Sebagai Tujuan Penegakan Hukum}

Aspek kemanfaatan sebagai tujuan penegakan hukum memiliki pandangan bahwa penegakan hukum harus mengutamakan kemanfaatan atau kedayagunaan dalam proses penegakannya. Teori ini berpendapat bahwa penegakan hukum juga terpaksa harus memiliki sifat kompromi demi menciptakan suatu kemanfaatan. Selain itu, menurut teori ini hukum yang baik adalah yang dapat memberikan manfaat atau kedayagunaan untuk manusia. ${ }^{28}$ Sehingga baik atau buruk dan berhasil atau tidak berhasilnya suatu sistem penegakan hukum di suatu negara dapat dinilai dari sejauh mana hukum itu dapat memberikan manfaat bagi masyarakat pada negara tersebut.Menurut pendapat dari Jeremy Bentham, hukum dan negara ada semata-mata hanya untuk manfaat sejati, yakni demi kebahagian mayoritas rakyat. ${ }^{29}$ Sedangkan John Rawls di dalam teorinya yang disebut sebagai Teori Rawls berpendapat bahwa hukum haruslah menciptakan suatu masyarakat yang ideal, yaitu masyarakat yang mencoba memperbesar suatu kebahagiaan dan memperkecil ketidakbahagiaan. ${ }^{30}$

Dari teori-teori tersebut dapat dipahami bahwa pada tinjauan kali ini harus menitikberatkan pada manfaat yang di dapatkan dari suatu pemidanaan berupa pidana penjara yang pada kenyataannya masih seringkali diberlakukan terhadap pecandu narkotika di Indonesia.Dalam meninjau pemidanaan terhadap pencandu narkotika di Indonesia berdasarkan aspek kemanfaatan,

\footnotetext{
${ }^{28}$ Margono, Asas Keadilan Kemanfaatan dan Kepastian Hukum dalam Putusan Hakim, Jakarta,

Sinar Grafika, 2019, h. 110.

${ }^{29} \mathrm{Ibid}, \mathrm{h} .111$.

${ }^{30}$ Ibid.
} 
penulis akan membagi tinjauan berdasarkan dua sudut pandang yaitu kemanfatan bagi pecandu narkotika itu sendiri dan kemanfaatan bagi negara Indonesia. Pertama, bagi pecandu narkotika,Apabila ditinjau dari sudut pandang ilmu viktimologi, pecandu narkotika sering kali disebut sebagai self victimization atau victimless crime yang pada intinya memandang seorang pecandu narkotika sebagai seorang korban dari kejahatan yang dilakukan oleh dirinya sendiri. ${ }^{31}$ Selain itu fakta mengatakan bahwa seorang pecandu narkotika adalah seorang pesakitan. Hal ini tidak lepas disebabkan oleh zat adiktif yang terkandung di dalam narkotika, dimana zat tersebut dapat menyebabkan ketergantungan pada diri seseorang yang telah mencobanya. Kecanduan terhadap narkotika juga dapat merusak kesehatandari pecandu itu sendiri baik secara fisik maupun psikologisnya, adapun efek jangka panjang yang dapat ditimbulkan adalah potensi terjadinyagangguan kejiwaan, kerusakan pada hati, kehilangan ingatan, gangguan seksual hingga resiko kematian akibat overdosis. ${ }^{32}$ Oleh sebab dampak buruk tersebut, maka tidak salah mengatakan bahwa seorang pecandu narkotika juga dapat dikatakan sebagai korban apabila dilihat dari sudut pandang ilmu kesehatan.

Karena hal tersebut, sudah seharusnya seorang pecandu narkotika mendapatkan pengobatan baik berupa detoksifikasi atau tahapan yang ditujukan untuk menghilangkan racun akibat narkoba, rehabilitasi yang ditujukan agar seorang pemakai dapat kembali hidup secara normal dan tahap tindak lanjut lainnya. ${ }^{33}$ Meskipun sebenarnya rehabilitasi bisa saja diberikan bagi pecandu narkotika di dalam Lembaga Pemasyarakatan, akan tetapi dengan mempertimbangkan situasi terkini Lembaga Pemasyara-

\footnotetext{
${ }^{31}$ Bambang Waluyo, Viktimologi Perlindungan Korban dan Saksi, Jakarta, Sinar Grafika, 2019 (selanjutnya disingkat Bambang Waluyo II), h. 19.

${ }^{32}$ Yasonna H. Laoly, Jerat Mematikan Perspektif Kesejahteraan Ekonomi Dalam Penyalahgunaan Narkoba, Jakarta, PT Pustaka Alvabet, 2019,h. 33.

${ }^{33}$ Hari Sasangka, Loc.Cit.
}

katan di Indonesia yang dipenuhi berbagai permasalahan seperti overkapasitas pada Lembaga Pemasyarakatan dan lemahnya pengawasan di dalam Lembaga Pemasyarakatan itu sendiri, sehingga Lembaga Pemasyarakatan dinilai masih belum mampu menjadi tempat yang dapat menyembuhkan serta memperbaiki seorang pecandu narkotika dari jerat ketergantungan narkotika. Rehabilitasi pada dasarnya tidak ditujukan sebagai suatu bentuk penghukuman akan tetapi rehabilitasi didasarkan pada tujuan pemikiran bahwa seorang pecandu narkotika adalah orang yang memerlukan penyembuhan $^{34}$, sehingga menempatkan seorang pecandu narkotika ke dalam Lembaga Pemasyarakatan yang dinilai sebagai tempat penghukuman atau penjatuhan derita bagi pelaku tindak pidana dinilai tidak tepat. Faktanya kehidupan di dalam Lembaga Pemasyarakatan memang penuh dengan problematika, problematika tersebut dinamakan prisonisasi, yang mana prisonisasi ini berpotensi membuat seseorang menjadi lebih buruk dibanding sebelum ditempatkan di dalam Lembaga Pemasyarakatan. ${ }^{35}$ Berdasarkan kondisi tersebut, meskipun rehabilitasi dapat dilakukan di dalam Lembaga Pemasyarakatan, akan tetapi potensi negatif yang mengancam kesembuhan dari seorang pecandu narkotika jauh lebih besar apabila ditempatkan di dalam Lembaga Pemasyarakatan, bahkan berpotensi memperparah keadaan dari pecandu narkotika tersebut. Selain itu apabila hal ini terjadi, tentu ini merupakan suatu bentuk pengkhianatan terhadap Undang-Undang Nomor 35 Tahun 2009 Tentang Narkotika yang mengamanatkan rehabilitasi untuk ditujukan guna memperbaiki serta menyembuhkan seorang pecandu narkotika. Sehingga meskipun pemidanaan berupa pidana penjara mungkin memiliki fungsi memberikan efek jera bagi-

\footnotetext{
${ }^{34}$ Ricky Gunawan, et. al, Membongkar Praktik Pelanggaran Hak Tersangka di Tingkat Penyidikan: Studi Kasus Terhadap Tersangka Kasus Narkotika di Jakarta, Jakarta, Lembaga Bantuan Hukum

Masyarakat, 2012, h. 75.

${ }^{35}$ Ratna WP, Op.Cit.,h. 110.
} 
pecandu narkotika, akan tetapi dampak negatif yang ditimbulkan jauh lebih banyak dibandingkan manfaatnya, sehingga penulis berkesimpulan bahwa aspek kemanfaatan yang ditujukan bagi seorang pecandu narkotika tidak dapat dipenuhi apabila seorang pecandu narkotika di jatuhi dengan pidana penjara.

Kedua, terkait dengan kemanfaatan bagi negara Indonesia yang diperoleh dari penjatuhan pidana penjara bagi pecandu narkotika. Pada faktanya pemidanaan yang dijatuhkan terhadap pecandu narkotika selama ini tidak dapat dikatakan efektif dalam menekan angka jumlah penyalahgunaan narkotika di Indonesia yang pada faktanya selalu bertambah dalam 3 tahun belakangan ini. Sebaliknya, penjatuhan rehabilitasi bagi para pecandu narkotika dipercaya akan mampu menekan angka dari peredaran narkotika itu sendiri. Hal ini disebabkan oleh rehabilitasi yang bertujuan untuk kesembuhan, pemulihan serta membebaskan pecandu narkotika dari ketergantungan terhadap narkotika, sehingga usai menjalankan masa rehabilitasi diharapkan para pecandu narkotika dapat pulih dan sembuh seutuhnya. Hal ini juga berguna untuk mempersempit pergerakan dari para pengedar narkotika, karena semakin banyak pecandu narkotika yang sembuh, maka semakin berkurang pula lahan bagi pengedar narkotika untuk mencari keuntungan, mengingat selama ini para pecandu narkotika tersebutlah yang menjadi target utama dari peredaran gelap narkotika. Meskipun rehabilitasi belum pula terbukti dapat sepenuhnya berhasil, akan tetapi cara ini sudah sesuai dengan paradigma hukum modern yang pada intinya bertujuan untuk menekan demand sekaligus menekan supply narkotika illegal, sehingga diharapkan mampu berdampak pada penurunan prevalensi penyalahgunaan narkotika serta peredaran gelap narkotika. ${ }^{36}$

Sebagai perbandingan, di negara Belanda kepemilikan semua jenis narkotika merupakan pelanggaran hukum pidana,

\footnotetext{
${ }^{36}$ Anang Iskandar, Op.Cit.,h. 37.
}

akan tetapi segala bentuk penegakan hukum terhadap seorang penyalah guna bersifat rehabilitatif. Begitupun dengan negara Portugal dan negara bagian New South Wales, yang mana mengedepankan penegakan hukum yang bersifat rehabilitatif bagi penyalah guna yang menyalahgunakan narkotika untuk dirinya sendiri. Hasilnya, di negara Belanda terjadi penurunan pengguna narkotika pemula dan penggunaan hard drug, begitupun di Negara Portugal dimana tercatat terjadi penurunan angka penggunaan narkotika pada kalangan usia produktif serta penurunan pada angka peredaran gelap narkotika, serta pada negara bagian New South Wales terjadi pula penurunan tingkat penggunaan narkotika maupun penurunan pada biaya penegakan hukum. ${ }^{37}$ Meskipun kebijakan-kebijakan pada negara-negara tersebut tentu tidak bisa diterapkan secara mutlak di Indonesia yang mungkin disebabkan oleh beberapa faktor perbedaan seperti kebudayaan, perbedaan kebiasaan, dan lain sebagainya, akan tetapi negara-negara tersebut telah membuktikan bahwa upaya penegakan hukum yang bersifat rehabilitatif jauh lebih bermanfaat dalam memerangi peredaran narkotika dibandingkan dengan pemidanaan berupa pidana penjara. Selain itu, penjatuhan pidana penjara bagi pecandu narkotika justru berpotensi menambah masalah bagi negara Indonesia, seperti terjadinya overkapasitas pada Lembaga Pemasyarakatan yang kemudian menyebabkan sulitnya mengontrol kehidupan di dalam sana, hingga berpotensi menyebabkan semakin berkembangnya peredaran narkotika yang disebabkan oleh bercampurnya para pengedar dan pecandu narkotika di dalam Lembaga Pemasyarakatan seperti yang telah dijelaskan sebelumnya. Sehingga berdasarkan tinjauan tersebut, penulis menilai bahwa pemidanaan terhadap pecandu narkotika tidak dapat memenuhi aspek kemanfaatan baik bagi pecandu narkotika itu sendiri maupun bagi negara Indonesia.

\footnotetext{
${ }^{37}$ Ibid., h. 43.
} 


\section{Dampak Pemidanaan Terhadap Pe- candu Narkotika}

Apabila ditinjau lebih jauh mengenai dampak yang ditimbulkan dari pemidanaan berupa pidana penjara yang kerap diberlakukan bagi pecandu narkotika di Indonesia, dampak positif dari adanya model pemidanaan tersebut hanyalah memberikan efek jera bagi pecandu narkotika untuk tidak mengulangi perbuatannya kembali, meskipun pemidanaan sebenarnya tidak menjamin sepenuhnya terpenuhinya hal tersebut. Hal ini disebabkan oleh kondisi Lembaga Pemasyarakatan di Indonesia yang mengalami overkapasitas sehingga fungsi kontrol terhadap kehidupan di dalam Lembaga Pemasyarakatan menjadi sulit untuk dilaksanakan. Selain itu, terdapat satu lagi permasalahan serius yang terjadi di dalam Lembaga Pemasyarakatan di Indonesia yang sangat tidak memungkinkan seorang pecandu narkotika dapat sembuh apabila ditempatkan di dalamnya, yaitu peredaran narkotika yang ternyata juga terjadi di dalam Lembaga Pemasyarakatan. ${ }^{38}$ Sudah terdapat banyak kasus peredaran narkotika pada Lembaga Pemasyarakatan yang terjadi di Indonesia hingga saat ini, bahkan berdasarkan survey dan investigasi yang dilakukan oleh BNN mengungkapkan bahwa sekitar 90 persen peredaran narkotika yang terjadi di Indonesia dikendalikan dari balik Lembaga Pemasyarakatan. ${ }^{39}$ Angka tersebut tentu terhitung sangat besar, dan berdasarkan kasus-kasus peredaran narkotika yang telah terjadi pada Lembaga Pemasyarakatan selama ini, tentu menempatkan seorang pecandu narkotika ke dalamnya bukan merupakan langkah yang tepat.

Hal ini juga menyebabkan terciptanya potensi bercampurnya para pecandu narkotika dengan pengedar serta bandar narkotika

\footnotetext{
${ }^{38}$ Sugeng Pujileksono, Sosiologi Penjara, Malang, Intrans Publishing, 2017, h. 189.

39 " Kepala BNN: 90 Persen Transaksi Narkoba

Dikendalikan dari Dalam Lapas"

$<$ https://regional.kompas.com/read/2019/08/14/1116 4041/kepala-bnn-90-persen-transaksi-narkobadikendalikan-dari-dalam-lapas $>$. Diakses tanggal 8 April 2020, Pukul 14.53 WIB.
}

yang tak lain juga disebabkan oleh terjadinya overkapasitas pada Lembaga Pemasyarakatan di Indonesia, sehingga menyebabkan sulitnya mengontrol kondisi kehidupan di dalam Lembaga Pemasyarakatan. Dengan kondisi demikian, pecandu narkotika dapat dengan mudah menjadi target dari peredaran narkotika di dalam Lapas bahkan dalam beberapa kasus para pecandu narkotika juga dapat direkrut menjadi seorang pengedar narkotika yang baru. ${ }^{40}$ Sehingga berdasarkan hal tersebut, kemungkinan yang akan terdampak bukan hanya pada diri seorang pecandu narkotika saja, melainkan akan berdampak luas pula pada negara Indonesia. Hal ini disebabkan karena apabila ternyata seorang pecandu narkotika ketika selesai menjalankan masa hukumannya di dalam Lembaga Pemasyarakatan malah menjadi seorang pengedar narkotika yang baru, tentu hal tersebut akan semakin merepotkan Negara dalam upaya memerangi peredaran gelap narkotika. Sehingga pemidanaan terhadap pecandu narkotika ini dinilai tidak efektif karena berpotensi akan berdampak buruk baik bagi pecandu narkotika itu sendiri maupun bagi Negara indonesia.

\section{Penutup}

Berdasarkan uraian penelitian yang telah dilakukan, peneliti mendapatkan kesimpulan sebagai berikut :

1. Berdasarkan tinjauan-tinjauan pada pembahasan, dapat ditarik kesimpulan bahwa pemidanaan yang diberlakukan bagi para pecandu narkotika tidaklah dapat memenuhi tujuan dari penegakan hukum itu sendiri. Pemidanaan bagi para pecandu narkotika bukanlah hal yang tepat diberlakukan. Dimulai dari adanya perbedaan penyelesaian kasus serupa yang menimbulkan tercederainya rasa keadilan, hingga ketidakpastian hukum akibat perbedaan pemahaman di antara aparat penegak hukum saat menangani kasus yang melibatkan pecandu narkotika. Selain itu pemidanaan terhadap pecandu narkotika dinilai tidak memiliki kemanfaat

\footnotetext{
${ }^{40}$ Sugeng Pujileksono, Op.Cit., h. 192.
} 
an yang besar, sehingga baik aspek keadilan, kepastian hukum, maupun kemanfaatan dinilai belum dapat terpenuhi dari adanya pemidanaan terhadap pecandu narkotika.

2.Faktanya, dampak negatif dari pemidanaan terhadap pecandu narkotika di Indonesia lebih besar dibandingkan dengan dampak positif yang dapat ditimbulkan. Mengingat beberapa permasalahan terkait kondisi Le- mbaga Pemasyarakatan di Indonesia saat ini, maka menjatuhkan pidana penjara bagi seorang pecandu narkotika dapat dinilai bukan merupakan sesuatu yang efektif dan dapat mendapatkan dampak positif dalam memerangi penyalahgunaan maupun peredaran gelap narkotika di Indonesia.

a. Buku

\section{DAFTAR PUSTAKA}

Apeldoorn, L. v. 2013, Pengantar Ilmu Hukum, PT Pradnya Paramita, Jakarta.

Arbijoto. 2010, Kebebasan Hakim Analisis Kritis Terhadap Peran Hakim Dalam Menjalankan Kekuasaan Kehakiman, Diadit Media, Jakarta.

Bakhri, Syaiful. 2012, Tindak Pidana Narkotika dan Psikotropika Suatu Pendekatan Melalui Kebijakan Hukum Pidana, Gramata Publishing, Jakarta.

Dellyana, Shanty. 1988, Konsep Penegakan Hukum, Liberty, Yogyakarta.

Gunawan, Ricky, et. al. 2012, Membongkar Praktik Pelanggaran Hak Tersangka di Tingkat Penyidikan: Studi Kasus Terhadap Tersangka Kasus Narkotika di Jakarta, Lembaga Bantuan Hukum Masyarakat, Jakarta.

Hamzah, Andi. 2017, Hukum Acara Pidana Indonesia, Sinar Grafika, Jakarta.

Hiariej, Eddy O.S. 2016, Prinsip-Prinsip Hukum Pidana, Cahaya Atma Pustaka, Yogyakarta.

Iskandar, Anang. 2019, Penegakan Hukum Narkotika Rehabilitatif terhadap Penyalah Guna dan Pecandu Represif terhadap Pengedar, PT Elex Media Komputindo, Jakarta.

Kadarmanta, A. 2010, Narkoba Pembunuh Karakter Bangsa, PT. Forum Media Utama, Depok.

Kanter, E.Y dan S.R. Sianturi. 2002, Asas-Asas Hukum Pidana di Indonesia dan Penerapannya, Storia Grafika, Jakarta.

Laoly, Yasonna H. 2019,Jerat Mematikan Perspektif Kesejahteraan Ekonomi Dalam Penyalahgunaan Narkoba, PT Pustaka Alvabet, Jakarta.

Margono. 2019,Asas Keadilan Kemanfaatan dan Kepastian Hukum dalam Putusan Hakim, Sinar Grafika, Jakarta.

Pujileksono,Sugeng. 2017,Sosiologi Penjara, Intrans Publishing, Malang.

Renggong,Ruslan. 2017,Hukum Pidana Khusus Memahami Delik-delik di Luar KUHP, Kencana, Jakarta.

Sasangka, Hari. 2003, Narkotika dan Psikotropika Dalam Hukum Pidana Untuk Mahasiswa dan Praktisi serta Penyuluh Masalah Narkoba, Mandar Maju, Bandung.

Setiadi, Edi dan Kristian. 2017, Sistem Peradilan Pidana Terpadu dan Sistem Penegakan Hukum di Indonesia, Prenadamedia Group, Jakarta.

Sujono, AR dan Bony Daniel. 2013,Komentar Dan Pembahasan Undang-Undang Nomor 35 Tahun 2009 Tentang Narkotika, Sinar Grafika, Jakarta.

Sunggono, Bambang. 2016, Metodologi Penelitian Hukum, PT RajaGrafindo, Jakarta.

Supramono, Gatot. 2009, Hukum Narkoba Indonesia, Djambatan, Jakarta.

Waluyo, Bambang. 2016, Penegakan Hukum Di Indonesia, Sinar Grafika, Jakarta.

- 2018,Pidana dan Pemidanaan, Sinar Grafika, Jakarta. 


\section{Jakarta.}

2019,Viktimologi Perlindungan Korban dan Saksi, Sinar Grafika,

WP,Ratna. 2017,Aspek Pidana: Penyalahgunaan Narkotika Rehabilitasi Versus Penjara (Menyoroti Pasal 127 UU No. 35 Tahun 2009), LEGALITY, Yogyakarta.

Zulfa, Eva Achjani, Anugerah Rizki Akbari dan Zakky Ikhsan Samad. 2017,Perkembangan Sistem Pemidanaan Dan Sistem Pemasyarakatan, PT RajaGrafindo Persada, Depok.

Zulfa, Eva Achjani dan Indriyanto Seno Adji. 2011,Pergeseran Paradigma Pemidanaan, CV Lubuk Agung, Bandung.

\section{b. Peraturan Perundang Undangan}

Undang-Undang Nomor 8 Tahun 1981 Tentang Kitab Undang-undang Hukum Acara Pidana (KUHAP).

Undang-Undang Nomor 35 Tahun 2009 tentang Narkotika.

Surat Edaran Mahkamah Agung (SEMA) Nomor 4 Tahun 2010 tentang penetapan penyalahguna, dan Pecandu Narkotika ke dalam Lembaga Rehabilitasi Medis dan Rehabilitasi Sosial.

\section{c. Jurnal}

Istri. A.A. 2012, Perlindungan Hukum Terhadap Korban Penyalahguna Narkotika Dengan Berlakunya Undang-Undang Nomor 35 Tahun 2009 Tentang Narkotika, Fakultas Hukum Universitas Udayana, Denpasar.

Gani, Hafied Ali. 2015, Rehabilitasi Sebagai Upaya Depenalisasi Bagi Pecandu Narkotika, Fakultas Hukum Universitas Brawijaya, Malang.

Laksana, Andri Winjaya. 2015, Tinjauan Hukum Pemidanaan Terhadap Pelaku Penyalahgunaan Narkotika Dengan Sistem Rehabilitasi, Fakultas Hukum Universitas Islam Sultan Agung, Semarang.

\section{d. Sumber Internet}

"Penggunaan Narkotika di Kalangan Remaja Meningkat" < https://bnn.go.id/penggunaannarkotika-kalangan-remaja-meningkat/>. Diakses tanggal 2 Oktober 2019, Pukul 01.40 WIB.

"BNN: Pemakai Narkoba di Indonesia Capai 3,5 Juta Orang Pada 2017" $<$ https://www.liputan6.com/news/read/3570000/bnn-pemakai-narkoba-diindonesia-capai-35-juta-orang-pada-2017>. Diakses tanggal 8 April 2020, Pukul $22.41 \mathrm{WIB}$

"Kepala BNN: Pengguna Narkoba Pada 2019 Tembus 3,6 Juta Orang" $<$ https://www.liputan6.com/news/read/4127338/kepala-bnn-penggunanarkoba-pada-2019-tembus-36-juta-orang>. Diakses tanggal 8 April 2020, Pukul 22.45 WIB

"Disparitas Putusan dan Pemidanaan yang Tidak Proporsional" $<$ https://www.hukumonline.com/berita/baca/lt524a2ce258cb5/disparitas-putusandan pemidanaan-yang-tidak-proporsional/>. Diakses tanggal 7 Februari 2020, Pukul 16.06 WIB.

"Kepala BNN: 90 Persen Transaksi Narkoba Dikendalikan dari Dalam Lapas" $<$ https://regional.kompas.com/read/2019/08/14/11164041/kepala-bnn-90-persentransaksi-narkoba-dikendalikan-dari-dalam-lapas $>$. Diakses tanggal 8 April 2020, Pukul 14.53 WIB. 
Lex Librum : Jurnal Ilmu Hukum, Vol. 7 No.1, Desember 2020, hal. 17-32 